\title{
The Determinants of Capital Structure Decisions: Evidence from Chinese Listed Companies
}

\author{
Sunitha Vijayakumaran(Corresponding author) \\ Department of Commerce \\ Faculty of Management Studies and Commerce \\ University of Jaffna, Sri Lanka \\ Ratnam Vijayakumaran \\ Department of Financial Management \\ Faculty of Management Studies and Commerce \\ University of Jaffna, Sri Lanka
}

Received: April 27, 2018 Accepted: Nov. 13, $2018 \quad$ Published: December 1, 2018

doi:10.5296/ajfa.v10i2.13065 URL: https://doi.org/10.5296/ajfa.v10i2.13065

\begin{abstract}
In this paper, we examine the determinants of leverage in the context of China using a sample of 1844 Chinese non-financial firms over the period 2003 to 2010. This study shows that the average leverage ratio of Chinese listed firms is similar to those observed in other developing countries. The study also finds thatsize, tangibility, volatility and firm age are positively and significantly associated with leverage. Firm's profitability has statistically significant negative impact on leverage. Furthermore, we find that firm size, profitability, tangibility, volatility and firm age are the robust determinants of leverage of Chinese listed firms.
\end{abstract}

Keywords: Capital Structure, Leverage, firm size, profitability, tangibility, growth opportunities, volatility, China.

JEL Classification F30; G10; G32 


\section{Introduction}

Corporate capital structure decisions are not only important for firms to maximize their value but also for the growth and stability of firms and the corporate economy as a whole (Jensen and Meckling, 1976; Benito, 2003). Firm financing patterns have long been the object of study in the corporate finance literature (Haris \& Raviv, 1991). The main issue of debate revolve primarily around the optimal capital structure that maximizes the value of the firm (e.g., Modigliani and Miller, 1958 and 1963; Miller, 1977). Capital structure means the mix of different sources of financing such as equity and debt (Panday, 2006). Capital structure choices of corporations have traditionally been analysed in the Modigliani-Miller (1958) framework, expanded to incorporate taxes, bankruptcy costs, agency cost, and asymmetric information issues (such as signalling, adverse selection). The trade-off theory, pecking order theory (Myers and Majluf, 1984; Myers, 1984), and agency theory (Jensen and Meckling, 1976) are main theories that explain the use of leverage in firms' capital structure.

A large number of studies, for example Titman and Wessels (1988), Wald (1999), have empirically examined determinants of capital structure in the context of developed economies. Most early papers examine the case of US companies (see Haris and Raviv(1991) and Graham, \& Leary, (2011) for reviews), whilst Rajan and Zingales (1995) test the theoretical and empirical lessons learnt from the US studies for the G7 countries. These authors find a similar behaviour of leverage across countries, thus refuting the idea that firms in bank-oriented countries are more leveraged than those in market-oriented countries. (Note1) Rajan and Zingales (1995) also find that the determinants of capital structure that have been reported for the USA (size, growth opportunities, profitability, and tangible assets) are important in other countries as well. They show that a good understanding of the relevant institutional context (bankruptcy law, fiscal treatment, ownership concentration, and accounting standards) is required when identifying the fundamental determinants of capital structure (Note that capital structure, leverage and debt capital or debt financing are used interchangeable throughout the paper). Recently, there has been a growing body of literature on capital structure decisions from developing countries, for example Wiwattanakantang (1999), Booth et al. (2001), Deesomsak et al. (2004), Kim et al. (2006), and Črnigoj and Mramor (2009).

In the context of China, a handful of empirical studies examine capital structure decisions (for example, Chen, 2004; Huang and Song, 2006; Zou and Xiao, 2006; Qian et al., 2009; Moosa et al., 2011). A common feature of all these studies based on Chinese listed companies is that they use data before 2005. Therefore, these studies do not consider changes occurred after the major split-share reform initiated by Chinese Securities Regulatory Committee (CSRC hereafter) and Chinese government in 2005. The aim of the 2005 split-share structure reform is to convert non-tradable shares into tradable shares in order to facilitate the liquidity in the secondary market. Before implementing the reform, the non-tradable shareholders of a firm have to negotiate with tradable shareholders to ensure that they get a suitable compensation package before trading occurs. (Note 2) This study, therefore, provides first empirical evidence using a longer period of latest Chinese listed company data on the effects of ownership reform on the corporate financing decisions. 
The reminder of the paper is organized as follows. Section 2 reviews the theories and prior studies related to capital structure decisions and develops testable hypotheses. Section 3 presents regression model and discusses our estimation methodologies. Section 4 describes data and presents descriptive statistics. In Section 5, we discuss our empirical results, before concluding in Section 6.

\section{Review of the literature and hypothesis development}

This section presents the main capital structure theories: the static trade-off theory, the pecking order theory and the agency theory. The aim of reviewing the capital structure theories is to develop a theoretical framework for predicting the effects of the determinants of capital structure. In addition, we review prior evidence and develop hypotheses.

\subsection{Relevant capital structure theories}

For a long time, the issue of capital structure choices and the resulting effect on the value of the firm has been a controversial and much disputed area. The main issue of debate revolve primarily around the optimal capital structure that maximizes the value of the firm (Modigliani and Miller, 1958 and 1963; Miller, 1977). Capital structure means the mix of different sources of financing such as equity and debt (Pandy, 2008). In fact, the debate on the modern theory of capital structure began with the seminal paper of Modigliani and Miller (1958) which shows that subject to some conditions, the impact of debt financing on the value of the firm is irrelevant. They contend in their first proposition that the market value of any firm is independent to its capital structure, and is given by capitalizing its expected return at the rate appropriate to the risk class (i.e. the levels of risk of the firm) (Modigliani and Miller 1958). This first proposition has been criticized and the main argument is that it is theoretically very sound but is based on the assumptions of perfect capital market, no taxes (personal or corporate), no distress costs and equal access to information which are not valid in reality.

Following the work of Modigliani and Miller (1958), the literature on capital structure has been expanded through many theoretical and empirical contributions. Scholars have placed much emphasis on releasing the assumptions made by Modigliani and Miller (1958), in particular by taking into account corporate taxes (Modigliani and Miller, 1963), bankruptcy costs (Stiglitz,1972; Titman,1984), agency costs (Jensen and Meckling, 1976), information asymmetries (Myers and Majluf, 1984; Myers, 1984), and imperfect capital markets (Baker and Jeffrey, 2002). The alternative theories that currently dominate the empirical studies include the trade-off theory, the pecking order theory and, the agency theory.

The trade-off theory is a result of releasing assumptions of 'no corporate taxes' and 'no financial distress costs' (i.e. bankruptcy costs). For example, Modigliani and Miller (1963) relaxed their assumptions by incorporating the effect of taxes on the cost of capital. Tax shields occur when firms use debt financing in their capital structure, as firms have to pay interest on debt which is generally tax deductible. Thus, interest payments act as a tax shield and allow the firm to increase its value. However, when considering the financial distress costs that arise from maintaining high levels of debt (e.g., bankruptcy costs) (Stiglitz, 1972), 
the value of the firm is determined by its net benefits (i.e. tax shield benefits minus costs). Therefore, the trade-off theory posits that firms maximise their value when the benefits that stem from debt (e.g. the tax shield and reduced costs of informational asymmetry attached to debt compared to outside equity) outweigh or equal the marginal cost of debt (e.g. bankruptcy costs, and agency costs) (Modigliani and Miller, 1963; Stiglitz, 1972; Jensen and Meckling, 1976; Myers, 1977; Titman, 1984).

The pecking order theory, which was developed by Myers and Majluf (1984) and Myers (1984) is linked to information asymmetries existing between insiders of the firm and outsiders (i.e. the capital market). The theory suggests that managers adapt their financing policies to minimise the cost of information asymmetries. Managers therefore prefer internal financing to external financing, and risky debt to equity since debt capital suffers less from information asymmetries than equity. That is debt is the first source of external finance on the pecking order and equity is issued only as a last resort, when the debt capacity is fully utilised.

The above two theories (i.e. the static trade-off and pecking order theories) are based on the assumption that the interest of the managers of a corporation with dispersed ownership is always aligned with that of shareholders. In contrast, the agency theory assumes that self-interested managers always pursue their own objectives at the expenses of shareholders (Jensen and Meckling, 1976).Jensen and Meckling (1976) formally model the agency costs of equity and debt capital in a modern corporation. They identify two types of agency conflicts namely, conflicts between managers and shareholders, and conflicts between shareholders and bond holders, and the related agency costs in a firm. As argued in Jensen and Meckling (1976) and Jensen (1986), debt capital not only brings in additional monitoring from outsiders (i.e. creditors) but also make managers commit to pay out cash, (i.e., it reduces the amount available to managers to overinvest). Therefore, using debt capital in the capital structure helps to reduce agency costs arising from conflicts between managers and shareholders (see S.Vijayakumaran (2016) and R. Vijayakumaran (2017) for a discussion on the governance role of debt). The use of debt capital in the capital structure leads to conflicts between debt-holders and equity holders because debt contracts give equity holders an incentive to invest sub-optimally (Jensen and Meckling, 1976). That is, managers (who act on behalf of shareholders) have incentive to shift funds from low-risk investment projects to high-risk ones in order to earn higher profit in the short term period (also known as assets substitution effect). Myers (1977) identifies another agency cost of debt. He argues that when firms are likely to go bankrupt in the near future, equity holders have no incentive to contribute new capital, even to invest in value-increasing projects because they bear the entire cost of the investment, while the returns may be captured mainly by debt-holders (i.e. the debt overhang problem). Therefore, the firm may undesirably forego positive NPV projects due to the conflicts of interest between equity holders and debt holders. This is well documented as "under invest problem" in the agency literature. Considering the benefits and costs of debt financing from an agency perspective, the agency theory provides predictions for the potential effects of the firm characterises on the use of debt capital in the firm. 


\subsection{The determinants of Capital structure and hypotheses}

Following Rajan and Zingales (1995), Titman and Wessels (1988), and Frank and Goyal (2009), the study uses seven important firm characteristics The expected relationship between the determinant variables and leverage are primarily guided by relevant theories as well as previous empirical studies.

\subsubsection{Firm size}

As discussed in Rajan and Zingales (1995), the theoretical prediction for the effect of size on leverage is ambiguous. It is argued that larger firms tend to be more diversified and have more tangible assets, stable cash flows and better reputations. The trade-off theory therefore postulates that compared to smaller ones, ceteris paribus, larger firms are expected to have a higher debt capacity due to a lower risk of bankruptcy (bankruptcy cost).

In contrast, the pecking-order theory suggests that, bigger firms are more likely to use less debt due to lower asymmetric information problems between insiders and outside investors (i.e. larger firms provide more information to lenders than smaller firms, so the cost of issuing new equity is lower than the debt issuing cost).

Previous empirical studies from developed countries (Titman and Wessels, 1988; Berger et al., 1997; Brailsfore et al., 2002; Florackis and Ozken, 2009), from developing economics (Wiwattanakantang, 1999; Booth et al., 2001; Pandey, 2001; Deesomsak et al., 2004), as well as in the context of Chinese firms (Chen and Strange, 2005; Zou and Xiao 2006; Haung and Song, 2006; Qian et al., 2009) all uniformly find that leverage is positively related to firm size. We therefore expect a positive relationship between firm size and leverage. Therefore, our hypothesis is that

$\mathrm{H}_{1}$ : There is a positive significant relationship between firm size and leverage.

\subsubsection{Profitability}

According to the static trade-off theory, the more profitable the firms, the greater the use of leverage, ceteris paribus, due to an increase in the tax shield benefits and, to a lower financial distress and agency costs of debt. Thus, this theory predicts that profitability is positively related to leverage. In contrast, there is an opposite prediction based on the pecking-order theory that the most profitable firms tend to borrow less. In other, the pecking-order theory suggests that firms first finance their investment using internal resources (i.e. retained profit), and then move to debt and new equity financing as a last resort.

Previous empirical findings on financing behaviour of firms in developed economies (Titman and Wessels, 1988; Chiarella et al., 1992; Allem, 1993; Wald, 1999; Rajan and Singales, 1995; Berger et al., 1997; Brailsfore et al., 2002; Fama and French, 2002; Frank and Goyal, 2003; Florackis and Ozken, 2009), and in emerging economies (Wiwattanakantang, 1999; Booth et al., 2001; Pandey, 2001; Deesomsak et al., 2004) find a negative relationship between leverage ratios and profitability. In the context of Chinese enterprises, several authors (Chen, 2004; Chen and Strange, 2005; Zou and Xiao 2006; Haung and Song, 2006; Qian et al., 2009) also report a similar relationship. In this study, the measure of earnings before interest and 
taxes scaled by total assets is employed to measure profitability (profit) of firms. We test the following hypothesis:

$\mathrm{H}_{2}$ : There is a negative significant relationship between profitability and leverage.

\subsubsection{Tangibility}

According to the pecking-order theory, firms with more fixed assets can easily access secured debt since tangible assets are used as collateral for debt. The static trade-off theory postulates that the larger the fixed assets of the firm (fixed assets are collateralised for debt and thus they reduce the risk of lenders), the lower the bankruptcy and financial distress costs. In line with the explanation of both theories, a positive relationship between tangibility and leverage is expected.

The findings of prior empirical research on leverage based on developed countries (Rajan and Singales, 1995; Berger et al., 1997; Wald, 1999; Brailsfore et al., 2002; Florackis and Ozken, 2009), and developing countries (Wiwattanakantang, 1999; Deesomsak et al., 2004) as well as China (Chen, 2004; Chen and Strange, 2005; Zou and Xiao 2006; Haung and Song, 2006; Qian et al., 2009), confirm this theoretical prediction. We thus expect a positive relationship between tangibility and leverage. In this study, tangibility (tang) is measured by net fixed assets normalized by total assets of the firm. We test the following hypothesis:

$\mathrm{H}_{3}$ : There is a positive significant relationship between tangibility and leverage.

\subsubsection{Growth opportunities}

According to the static trade-off theory, firms with high growth opportunities (which are a form of intangible assets) in the future are likely to be high risk, and this leads to a greater financial distress costs (Frank and Goyal, 2009). Therefore, an inverse relationship between growth opportunities and leverage is postulated. The pecking-order theory, in contrast, predicts a positive relationship between these variables since high-growth opportunity firms are likely to face more information asymmetry problems between insiders and outsiders (i.e. company managers know more about their future investment opportunities than outside investors). So these firms use more debt than equity in the financing hierarchy, since debt capital suffers less from information asymmetries.

Most empirical work on capital structure decisions show an opposite relationship between growth opportunities and leverage. Empirical studies from developed countries (Titman and Wessels, 1988; Rajan and Singales, 1995; Fama and French, 2002; Brailsfore et al., 2002; Frank and Goyal, 2009; Florackis and Ozken, 2009), from developing countries (Wiwattanakantang, 1999; Deesomsak et al., 2004), and from China (Zou and Xiao 2006; Haung and Song, 2006) obtain an inverse relationship between leverage and growth opportunities. Therefore, we also expect to find a negative relationship between the two variables in Chinese listed companies. Following Rajan and Zingales (1995) and Booth et al. (2001), we use the ratio of the sum of the market value of equity and the book value of debt to the book value of total assets to measure growth opportunities (growth) in our study. We test the following hypothesis: 
$\mathrm{H}_{4}$ : There is a negative significant relationship between growth opportunities and leverage.

\subsubsection{Non-debt tax shields}

Non-debt tax shields (nontaxshd) represent tax credits for investments and depreciation. Non-debt tax shields reduce a firm's tax payments and thus reduces the need for debt financing as a means to obtain tax advantages (Dammon and Senbet, 1988). That is, non-debt tax shields are substitutes for the tax benefits of debt financing. Therefore, the trade-off theory predicts a negative relationship between non-debt tax shields and leverage.

Previous empirical studies from developed countries (Wald, 1999; Chaplinsky and Niehaus, 1993), from developing countries (Wiwattanakantang, 1999; Deesomsak et al., 2004), as well as in the context of Chinese firms (Huang and Song, 2006; Qian et al., 2009), find an inverse relationship between non-debt tax shields and leverage. Therefore, we expect a similar relationship between non-debt tax shields and leverage. In this study, we use non-debt tax shields (notaxshd) measured by depreciation scaled by the total assets as an inverse proxy for tax shield advantage. We test the following hypothesis:

$\mathrm{H}_{5}$ : There is a significant negative relationship between non-debt tax shields and leverage

\subsubsection{Volatility}

According to the trade-off theory, a firm with higher earnings volatility has a higher probability of financial distress, since the volatility of earnings is the chief factor in determining firms' ability to meet debt obligations, such as interest charges. Therefore, an inverse relationship between volatility and leverage is postulated.

The findings of prior empirical studies on leverage based on developed countries (Titman and Wessels, 1988), and developing countries (Booth et al., 2001) as well as Chinese firms (Huang and Song, 2006) provide an inverse relationship between the volatility of earnings and leverage. We thus also expect to find a negative relationship between volatility and leverage. Following Johnson (2003), in this study, we define volatility (vol) as the standard deviation of the first differences of earnings before taxes and depreciation over the four years preceding the sample year, divided by average total assets for that period. We test the following hypothesis:

$\mathrm{H}_{6}$ : There is a negative significant relationship between volatility and leverage.

\subsubsection{Firm age}

Both the static-trade off and pecking-order theories are silent as regards the relationship between the firm age and leverage. However, based on the agency framework, some authors (e.g. Du et al., 2010) suggest that the older firms are less likely to face asymmetric information problems and should have much easier access debt financing compared to younger ones, ceteris paribus. Also, older firms are less likely to invest in risky projects, since they are established over many years and well reputed in the market (Diamond, 1991). Moreover, Tian and Estrin (2007) also mention that firm with long history can easily establish their reputation in the debt market, resulting older firms are more likely to have a higher 
leverage ratio than younger ones.

Previous empirical studies on Chinese firms (for example, Chen and Strange, 2005) find that firm age is positively related to leverage. In line with the above explanation and previous findings, we expect a positive relationship between firm age and leverage. In this study, firm age (firmage) is measured by the natural logarithm of years since the establishment of the firm. We test the following hypothesis:

$\mathrm{H}_{7}$ : There is a positive significant relationship between fim age and leverage.

\section{Model specification and estimation methodology}

In this section, we first present our model specifications: static baseline model and dynamic model. Following the model specification, the control variables that are used in the study are described lengthily with reference to relevant theories and prior empirical studies. Finally, estimation methodologies are discussed.

\subsection{Model specification}

$$
\begin{gathered}
\operatorname{lev}_{\mathrm{it}}=\beta_{0}+ \\
\beta_{1} \text { size }_{\mathrm{it}}+\beta_{2} \text { profit }_{\mathrm{it}}+\beta_{3} \text { tang }_{\mathrm{it}}+\beta_{4} \text { growth }_{\mathrm{it}}+\beta_{5} \text { nontaxshd }_{\mathrm{it}}+\beta_{6} \text { vol }_{i t}+ \\
\beta_{7} \text { firmage }_{\text {it }}+v_{i}+v_{t}+v_{j}+v_{k}+e_{i t .}
\end{gathered}
$$

where $i$ indexes firm, $t$ years. The term $v_{i}, v_{t}, v_{j}$, and $v_{k}$ represent time-invariant firm specific fixed effects, time-specific effects, industry effects, and effects of regional differences, respectively; $e_{i t}$ is a random/ idiosyncratic error term.

\subsection{Control variables}

In addition to the considered determinants of capital structure, we include year, industry and regional dummies as controls to control for year-specific, industry-specific and geographic effects.

Lemmon et al. (2008) provide strong evidence that firm-specific unobservable characteristics $\left(v_{i}\right)$ of the firm have a significant impact on firms' capital structure decisions. They vary across firms but are assumed to remain constant for each firm through time. They include variables such as the quality of management, managers' attitudes towards risk, and market reputation, etc. On the other hand, time-specific effects $\left(v_{t}\right)$, which we control for by including time dummies, vary through time but are the same for all the firms at a given point in time. $v_{t}$ captures macroeconomic factors such as interest rates, inflation and business cycle effects, which are outside the control of firms. Finally, $v_{j}$, effects of regional differences.

On the left hand side of the Equation (1), our dependent variable is the leverage ratio (the ratio of the book value of total debt to the book value of the firm's total assets) of firm $i$ in year $t$. On the right hand side a set of explanatory variables in addition to a set of control variables. The list of variables used in the paper, their definition and expected sign are summarized in Table1 1. 
Table 1. Definition of variables

\begin{tabular}{|c|c|c|c|c|}
\hline Variables & $\underline{\text { Name }}$ & & Measures & $\begin{array}{l}\text { Expected } \\
\underline{\text { sign }}\end{array}$ \\
\hline \multicolumn{5}{|c|}{ Capital structure variable } \\
\hline Leverage & lev & & Total debt / total assets & \\
\hline \multicolumn{5}{|c|}{ Determinants of leverage } \\
\hline Size & size & : & Natural logarithm of total real assets & + \\
\hline Profitability & profit & : & $\begin{array}{l}\text { ROA = Return on assets = Earnings before interest, } \\
\text { taxes and depreciation / total assets }\end{array}$ & - \\
\hline Tangibility & tang & : & Net fixed assets/ Total assets & + \\
\hline $\begin{array}{l}\text { Growth } \\
\text { opportunities }\end{array}$ & growth & : & $\begin{array}{l}\text { Ratio of the sum of the market value of equity and } \\
\text { the book value of debt to the book value of total } \\
\text { assets. Non-tradable share price is used to } \\
\text { calculate as the market value of the tradable } \\
\text { equity. }\end{array}$ & - \\
\hline Non-debt tax shield & notaxshd & $:$ & Depreciation / total assets & - \\
\hline Volatility & vol & : & $\begin{array}{l}\text { Standard deviation of the first differences of } \\
\text { earnings before taxes and depreciation over the } \\
\text { four years preceding the sample period, divided } \\
\text { by average total assets for that period. }\end{array}$ & - \\
\hline Firm age & firmage & : & $\begin{array}{l}\text { Log of the number of years since the } \\
\text { establishment of the firm }\end{array}$ & + \\
\hline Year dummies & $v_{t}$ & $:$ & Year dummies for the years 2003 to 2010 & \\
\hline Industry dummies & $v_{j}$ & : & $\begin{array}{l}\text { CSMAR B classification: } 5 \text { industries : Utilities, } \\
\text { Properties, Conglomerates, Industry, Commerce } \\
\text { (except financial industries) }\end{array}$ & \\
\hline Regional dummies & $v_{k}$ & : & $\begin{array}{l}\text { Dummies indicating whether the firm is located in } \\
\text { the Coastal, Western, or Central region of China }\end{array}$ & \\
\hline
\end{tabular}

Notes: '+' means that leverage increases with the variables, '-' means that leverage decreases with the variables.

\subsection{Estimation methodology}

In this study panel data estimation methodologies are used to examine the relationship between leverage and its determinants. Panel data analysis presents several advantages: it increases the degree of freedom owing to large number observation, reduces the possibility of collinearity among the explanatory variables, and results in more efficient estimates. We first use a pooled OLS (Ordinary Least Square) model. However, a pooled OLS does not take into account the potential unobserved firm heterogeneity, which may affect both the leverage and 
its determinants. Therefore, we use fixed effects method which allows us to control for unobservable heterogeneity and, therefore, eliminates the risk of obtaining biased estimates for our variables.

\section{Data and descriptive statistics}

In this section, we describe the dataset and sample that is used in our study, and explain how the data is processed. This section also provides a discussion on summary statistics and correlation analysis of our variables.

\subsection{Data and sample selection}

Our sample includes all the publicly held firms that have been listed on the Shanghai and Shenzhen stock exchanges over the period of 2003 to 2010. Data are collected from the China Stock Market and Accounting Research (CSMAR) database and Sino-fin. We first delete firms in the financial industry, since their capital structure is subject to many regulations. We then remove the potential outliers (i.e., extreme observations) by deleting observations below the $1^{\text {st }}$ and above the $99^{\text {th }}$ percentile of all our regression variables, expect dummy variables. Our final sample has 1844 Chinese firms and covers an unbalanced panel of 9624 firm-year observations.

\subsection{Summary statistics}

Table 2 presents descriptive statistics for the dependent variables, explanatory used in our regression analysis. Included are mean, median, standard deviations, minimum and maximum for the variables used in our study.

Table 2. Summary statistics of leverage, corporate governance, and control variables of Chinese listed firms over the period of 2003 to 2010

\begin{tabular}{lrrrrrr}
\hline Variables & Obs. & Mean & Median & Std. Dev. & Min & Max \\
\hline $\begin{array}{l}\text { Dependent variable } \\
\text { lev }\end{array}$ & 9624 & 0.503 & 0.505 & 0.214 & 0.058 & 3.061 \\
$\begin{array}{l}\text { Determinates of capital structure } \\
\text { size (billion RMB) }\end{array}$ & & & & & \\
profit & 9624 & 1.463 & 0.732 & 2.471 & 0.067 & 26.136 \\
tang & 9624 & 0.074 & 0.074 & 0.063 & -0.254 & 0.268 \\
growth & 9624 & 0.460 & 0.457 & 0.165 & 0.061 & 0.845 \\
notaxshd & 9624 & 2.082 & 1.659 & 1.237 & 0.807 & 8.504 \\
vol & 9624 & 0.025 & 0.022 & 0.015 & 0.000 & 0.081 \\
firmage & 9624 & 0.037 & 0.020 & 0.049 & 0.000 & 0.368 \\
\hline
\end{tabular}

Note: Definitions for all variables are provided in Table.1.

The minimum and maximum book values of leverage (lev) ratios for the sample firms range from $5.8 \%$ to $306.1 \%$ with an average of about $50 \%$ (median $50 \%$ ). This suggests that on average, half of total assets are financed by debt capital. Furthermore, this figure implies that our sample firms in China have similar mean leverage compared with the findings of the previous studies in developed economies. For example, in their sample of firms from G-7 
countries Rajan and Zingales (1995) report that mean leverage ratios (in book value) of $52 \%$ and $54 \%$, respectively for the United States and the UK. Moreover, the mean leverage ratio of Chinese listed firms is also similar to the ratios observed in developing countries (which average $51 \%$ according to Booth et al., 2001).

With regard to the determinants of leverage, the mean (median) of firm size (size) proxied by total assets of the firm is 1.463 billion RMB (732 billion RMB).(Note 3) Moreover, according to the sample, Chinese firms have an average profitability (profit) of $7.4 \%$, an average tangibility (tang) of $46 \%$, and average growth opportunity (growth) of $20.82 \%$.

Average (median) non- debt tax shield (notaxshd) for the sample firms is $2.5 \%(2.2 \%)$ while average (median) volatility $(\mathrm{vol})$ for the sample firms is $3.7 \%(2 \%)$. The average level of firm age (firmage) is 10.5 (10.00). Using data 972 Chinese PLCs in 2003, Chen and Strange (2005) find a mean of 6.60 for firm age. The mean values of these variables are comparable to those reported in studies on capital structure decision in the context of China, such as Huang and Song (2006) among others.

\section{Empirical results}

\subsection{Correlation analysis}

Table 3 reports the Pearson correlation coefficients between variables used in our regression analysis. Firstly, firm size (size) shows a positive and statistically significant correlation with total leverage (lev). Similarly, tangibility (tang) exhibits a positive association with total leverage. As expected, profitability (profit) and growth opportunities (growth)show a negative correlation with total leverage. The non-debt tax shield (nontaxshd) is positively and significantly related to leverage. Finally, firm age (firmage) is positively and significantly related to leverage.

Furthermore, Table 3 suggests that given that the observed correlation coefficients between independent variables are relatively low, multicollinearity should not be a serious problem in our study.

Table 3. Pearson correlation matrices

\begin{tabular}{lllllllll}
\hline & lev & size & profit & tang & growth & nontaxshd & vol & firmage \\
\hline lev & 1.00 & & & & & & & \\
size & $0.20^{*}$ & 1.00 & & & & & & \\
profit & $-0.33^{*}$ & $0.19^{*}$ & 1.00 & & & & & \\
tang & $0.20^{*}$ & $0.16^{*}$ & $0.09^{*}$ & 1.00 & & & & \\
growth & $-0.22^{*}$ & $-0.30^{*}$ & $0.21^{*}$ & $-0.21^{*}$ & 1.00 & & & \\
nontaxshd & $0.29^{*}$ & $-0.12^{*}$ & $-0.21^{*}$ & -0.01 & $0.07^{*}$ & 1.00 & & \\
vol & -0.02 & $0.06^{*}$ & $0.23^{*}$ & $0.50^{*}$ & $-0.08^{*}$ & $0.06^{*}$ & 1.00 & \\
firmage & $0.25^{*}$ & $0.15^{*}$ & $-0.10^{*}$ & $0.08^{*}$ & $-0.03^{*}$ & $0.29^{*}$ & $0.02^{*}$ & 1.00 \\
\hline
\end{tabular}

Notes: * denotes significance at the $5 \%$ level. See Table 1 for definitions of all variables. 


\subsection{Multivariate analysis}

This section discusses the empirical results. We first report estimates from model obtained using the pooled OLS and then firm fixed effects regressions which enable us to directly compare our results with previous studies based on developed countries as well as in the context of Chinese firms.

We can see that in Column 1 of Table4, firm size (size) attracts a positive and statistically significant coefficient. This is consistent with the previous empirical findings (e.g., Berger et al., 1997; Booth et al., 2001) and with the trade-off and agency theories, meaning that larger firms are more diversified compared to small ones and consequently, they are associated with a lower risk of bankruptcy cost and better borrowing capacity relative to smaller firms.

In line with the pecking-order theory, the relationship between profitability (profit) and leverage is negative and precisely determined in all columns. This provides additional support to findings of previous empirical studies in the context of Chinese listed companies. For example Chen (2004) proposes 'a new pecking-order', whereby firms use first retained profits, then equity financing, and debt capital as a last resort since bond markets in China are not very much developed. He finds that firms with more profitable projects tend to use less external financing since these firms have better access to internal financing than firms with lower profits. 


\section{Macrothink \\ Asian Journal of Finance \& Accounting \\ ISSN 1946-052X 2018, Vol. 10, No. 2}

Table 4. The traditional determinants of capital structure

\begin{tabular}{|c|c|c|c|}
\hline Variables & Predicted sign & $\begin{array}{c}\text { OLS } \\
\text { (1) }\end{array}$ & $\begin{array}{c}\text { Fixed effects } \\
\text { (2) }\end{array}$ \\
\hline \multirow[t]{2}{*}{ size } & + & $0.049^{* * *}$ & $0.050^{* * *}$ \\
\hline & & $(0.004)$ & $(0.008)$ \\
\hline \multirow[t]{2}{*}{ profit } & - & $-0.974^{* * *}$ & $-0.606^{* * *}$ \\
\hline & & $(0.066)$ & $(0.044)$ \\
\hline \multirow[t]{2}{*}{$\operatorname{tang}$} & + & $0.270^{* * *}$ & $0.175^{* * *}$ \\
\hline & & $(0.026)$ & $(0.023)$ \\
\hline \multirow[t]{2}{*}{ growth } & - & $-0.012^{* * *}$ & -0.002 \\
\hline & & $(0.005)$ & $(0.003)$ \\
\hline \multirow[t]{2}{*}{ nontaxshd } & - & $-1.109^{* * *}$ & -0.212 \\
\hline & & $(0.300)$ & $(0.352)$ \\
\hline \multirow[t]{2}{*}{ vol } & - & $1.042^{* * *}$ & $0.566^{* * *}$ \\
\hline & & $(0.140)$ & $(0.110)$ \\
\hline \multirow[t]{2}{*}{ firmage } & + & $0.053^{* * *}$ & $0.072^{* * *}$ \\
\hline & & $(0.009)$ & $(0.019)$ \\
\hline \multirow[t]{2}{*}{ Constant } & & $-0.744^{* * *}$ & $-0.815^{* * *}$ \\
\hline & & $(0.097)$ & $(0.172)$ \\
\hline Industry dummies & & yes & Yes \\
\hline Regional dummies & & yes & yes \\
\hline Year dummies & & yes & yes \\
\hline Firm fixed effects & & & yes \\
\hline Observations & & 9624 & 9624 \\
\hline$R^{2}$ & & 0.298 & 0.192 \\
\hline $\operatorname{adj} . R^{2}$ & & 0.296 & 0.191 \\
\hline F value & & 82.761 & 46.929 \\
\hline$P$ values & & 0.000 & 0.000 \\
\hline
\end{tabular}

Notes: Cluster robust standard errors are reported in columns 1 and 2 (clustered on firms). ${ }^{* *},{ }^{* *}$, and ${ }^{*}$ denote significance levels of $1 \%, 5 \%$ and $10 \%$, respectively. See Table 1 for definitions of all variables.

Tangibility (tang) is positively related to leverage in columns 1 and 2, suggesting that the larger the proportion of fixed to total assets the firm has, the lower the bankruptcy costs. This finding is in line with the trade-off theory and the findings of previous empirical studies (e.g., Rajan and Zinghales, 1995; Zou and Xiao, 2006). Furthermore, as can be seen in the OLS regression in columns 1, growth opportunities (growth) exhibit a negative significant coefficient in line with the static trade-off theory. This can also be explained following Myers (1977) who argues that high growth firms tend to use less leverage in order to reduce underinvestment problem. This result is also consistent with the findings of the previous studies in the context of China (Zou and Xiao 2006; Haung and Song, 2006; Moosa et al., 2011), from developed countries (Frank and Goyal, 2003; Florackis and Ozken, 2009), and from developing countries (see e.g., Wiwattanakantang, 1999; Deesomsak et al., 2004). However, results from the fixed effects model in column 2 indicate that growth opportunities 
have no significant impact on leverage ratios.

Column 1 of Table 4 show that the non-debt tax shield (nontaxshd) is negatively and significantly related to leverage, confirming non-debt tax shields are substitutes for the tax benefits of debt financing (DeAngelo and Masulis, 1980). This result is consistent with the findings of the previous empirical studies (Deesomsak et al., 2004; Wiwattanakantang, 1999; Qian et al., 2009). However, as shown in column (2), the coefficient on non-debt tax shields is insignificant in fixed effects regressions.

As can be seen in columns (1) and (2) of Table 4, the estimated coefficient on volatility (vol) is significantly positive. These results are consistent with the findings of the previous studies for Chinese listed firms (Qian et al., 2009).

Finally, the results from both OLS and fixed effects regressions in columns (1) and (2) indicate that firm age (firmage) is positively and significantly related to leverage, suggesting that older firms have much easier to access debt financing since they face less asymmetric information problems. This is consistent with the previous empirical finding in the context of Chinese listed firms (Chen and Strang, 2005).

So far, our analysis indicates that the average leverage ratio of Chinese listed firms is similar to those observed in other developing countries and the level of leverage is well explained by the firm specific determinants such as firm size, profitability, tangibility, volatility and firm age.

\section{Conclusions}

Capital structure theories have been subjected to extensive empirical testing in the context of developed economies, particularly the United States. In this paper, we study the determinants of leverage in the context of China. We use a sample of 1844 Chinese non-financial firms over the period 2003 to 2010 for our empirical analysis. This empirical study uses data after the 2005 spilt -share reform. Firstly, our study finds that that the average leverage ratio of Chinese listed firms is similar to those observed in other developing countries. The study also finds that size, tangibility, volatility and firm age are positively and significantly associated with leverage. Furthermore, firm's profitability has statistically significant negative impact on leverage. Furthermore, we find that we find that firm size, profitability, tangibility, volatility and firm age are the robust determinants of leverage of Chinese listed firms.

\section{Notes}

Note1. Market-oriented countries include the UK and the USA. Bank-oriented countries include Japan, France and Germany.

Note 2. The compensation package/ plan should be approved by $2 / 3$ of the total voting shareholders and the voting tradable shareholders.

Note 3. It should be noted that although firm size is measured as the logarithm of total real assets in the regression analysis, the figure reported in the descriptive statistics in Table 3.1 is not in logarithms as actual value is easier to interpret. 


\section{References}

Antoniou A., Guney Y., \& Paudyal K. (2008). The determinants of capital structure: Capital market-oriented versus bank-oriented institutions. Journal of Finance and Quantitative Analysis, 43(1), 59-92. https://doi.org/10.1017/S0022109000002751

Arellano, M., \& Bond, S. (1991). Some tests of specification for panel data: Monte Carlo evidence and an application to employment equations. The Review of Economic Studies, 58(2), 277-297. https://doi.org/10.2307/2297968

Berger, P.G., Ofek, E., \& Yermack, D.L. (1997) Managerial entrenchment and capital structure decisions. Journal of Finance, 52, 1411-1438. https://doi.org/10.1111/j.1540-6261.1997.tb01115.x

Baker, M., \& Jeffrey, W. (2002) Market timing and capital structure. Journal of Finance, 57, 1-32. https://doi.org/10.1111/1540-6261.00414

Bhabra, H. S., Liu, T., \& Tirtiroglu, D. (2008). Capital structure choice in a nascent market: Evidence from listed firms in China. Financial Management, 37(2), 341-364. https://doi.org/10.1111/j.1755-053X.2008.00015.x

Benito, A. (2003). The capital structure decisions of firms: is there a pecking order? Bank of Spain Working Paper No. 0310. Retrieved from https://ideas.repec.org/p/b-de/wpaper/0310.html

Booth, L., Aivazian, V., Demirguc-Kunt, A., \& Maksimovic, V. (2001). Capital structure in developing countries. Journal of Finance, 56(1), 87-130. https://doi.org/10.1111/0022-1082.00320

Bradley, M., Jarrell, G. A., \& and Kim, E. H. (1984). On the existence of an optimal capital structure: Theory and evidence. The Journal of Finance, 39(3), 857-878. https://doi.org/10.1111/j.1540-6261.1984.tb03680.x

Brandt, L., \& Li, H. (2003). Bank discrimination in transition economies: Ideology, information, or incentives? Journal of Comparative Economics, 31(3), 387-413. https://doi.org/10.1016/S0147-5967(03)00080-5

Chen, J. J. (2004). Determinants of capital structure of Chinese-listed companies. Journal of Business Research, 57(12), 1341-1351. https://doi.org/10.1016/S0148-2963(03)00070-5

Chen, J., Jiang, C., \& Lin, Y. (2014). What determine firms' capital structure in China? Managerial Finance, 40(10), 1024-1039. https://doi.org/10.1108/MF-06-2013-0163

Chen, J., \& Strange, R. (2005). The determinants of capital structure: Evidence from Chinese listed companies. Economic Change and Restructuring, 38(1), 11-35. https://doi.org/10.1007/s10644-005-4521-7

Choi, J., \& Richardson, M. (2016). The volatility of a firm's assets and the leverage effect. Journal of Financial Economics, 254-277. https://doi.org/10.1016/j.jfineco.2016.05.009 
DeAngelo, H., \& Masulis, R. W. (1980).Optimal capital structure under corporate and personal taxation. Journal of Financial Economics, 8(1), 3-29. https://doi.org/10.1016/0304-405X(80)90019-7

Deesomsak, R., Paudyal, K., \& Pescetto, G. (2004). The determinants of capital structure: evidence from the Asia Pacific region. Journal of Multinational Financial Management, 14(4), 387-405. https://doi.org/10.1016/j.mulfin.2004.03.001

DeJong, A., Nguyen, T. T., \& Kabir, R. (2008). Capital structure around the world: The roles of firm- and country-specific determinants. Journal of Banking and Finance, 32(9), 1954-1969. https://doi.org/10.1016/j.jbankfin.2007.12.034

De Miguel, A., \& Pindado, J. (2001). Determinants of capital structure: new evidence from Spanish panel data. Journal of Corporate Finance, 7(1), 77-99. https://doi.org/10.1016/S0929-1199(00)00020-1

Dickinson, G. (2001). Enterprise risk management: Its origins and conceptual foundation. The Geneva Papers on Risk and Insurance. Issues and Practice, 26(3), 360-366. https://doi.org/10.1111/1468-0440.00121

Dixon, R., Guariglia, A., \& Vijayakumaran, R. (2015). Managerial ownership, corporate governance and firms' exporting decisions: Evidence from Chinese listed companies. The European Journal of Finance, 1-39.

Faccio, M. (2006).Politically connected firms. The American Economic Review, 96(1), 369-386. https://doi.org/10.1257/000282806776157704

Fischer, E. O., Heinkel, R., \& Zechner, J. (1989). Dynamic capital structure choice: Theory and tests. The Journal of Finance, 44(1), 19-40. https://doi.org/10.1111/j.1540-6261.1989.tb02402.x

Flannery, M., \&Rangan, K. (2006).Partial adjustment toward target capital structures. Journal of Financial Economics, 79(3), 469-506. https://doi.org/10.1016/j.jfineco.2005.03.004

Frank, M. Z., \& Goyal, V. K. (2009). Capital structure decisions: Which factors are reliably important? Financial Management, $\quad 38(1), \quad$ 1-37. https://doi.org/10.1111/j.1755-053X.2009.01026.x

Diamond, D. W. (1991). Debt maturity structure and liquidity risk. The Quarterly Journal of Economics, 709-737. https://doi.org/10.2307/2937924

Dixon, R., Guariglia, A., \& Vijayakumaran, R. (2015). Managerial ownership, corporate governance and firms' exporting decisions: evidence from Chinese listed companies. The European Journal of Finance, 1-39.

Du, J., Guariglia, A., \& Newman, A. (2015). Do Social Capital Building Strategies Influence the Financing Behavior of Chinese Private Small and Medium Sized Enterprises?. Entrepreneurship Theory and Practice, 39(3), 601-631. https://doi.org/10.1111/etap.12051

Graham, J. R., \& Leary, M. T. (2011). A Review of Empirical Capital Structure Research and 
Directions for the Future. (April 7, 2011). Annual Review of Financial Economics, 3, 2011. https://doi.org/10.2139/ssrn.1729388

Grossman, S. J., \& Hart, O. D. (1982). Corporate financial structure and managerial incentives. In The economics of information and uncertainty (pp. 107-140).University of Chicago Press.

Guarigli, A., \& Vijayakumaran, S. (2013). Capital structure decisions and corporate governance: Evidence from the Chinese listed companies. Proceedings of 4th Asia-Pacific Business Research Conference, Singapore. Retrieved from https://wbiworldconpro.com/uploads/singapore-conference-013/finance/1380694634_310-Su nitha.pdf

Harris, M., \& Raviv, A. (1991).The theory of capital structure. The Journal of Finance, 46(1), 297-355. https://doi.org/10.1111/j.1540-6261.1991.tb03753.x

Hart, O \& Moore, J. (1995). Debt and seniority: an analysis of hard claims in constraining management. American Economic Review, 85, 567-585.

Hsiao, C. (1985). Benefits and limitations of panel data. Econometric Reviews, 4, 127-74. https://doi.org/10.1080/07474938508800078

Huang, G., \& Song, F. M. (2006). The determinants of capital structure: Evidence from China. China Economic Review, 17(1), 14-36. https://doi.org/10.1016/j.chieco.2005.02.007

Jensen, M. C. (1986). Agency costs of free cash flow, corporate finance, and takeovers. The American Economic Review, 76(2), 323-329.

Jensen, M., \& Meckling, M. (1976). Theory of the firm: Managerial behavior, agency costs and ownership structure. Journal of Financial Economics, 3(4), 305-360. https://doi.org/10.1016/0304-405X(76)90026-X

Johnson, S. (2003). Debt maturity and the effects of growth opportunities and liquidity risk on leverage, Review of Financial Studies, 16, 209-236. https://doi.org/10.1093/rfs/16.1.0209

Lemmon, M. L., Roberts, M. R., \& Zender, J. F. (2008). Back to the beginning: persistence and the cross-section of corporate capital structure. The Journal of Finance, 63(4), 1575-1608. https://doi.org/10.1111/j.1540-6261.2008.01369.x

Kim, H., Heshmati, A., \& Aoun, D. (2006). Dynamics of capital structure: The case of Korean listed manufacturing companies. Asian Economic Journal, 20(3), 275-302. https://doi.org/10.1111/j.1467-8381.2006.00236.x

Miller, M. (1977). Debt and taxes.Journal of Finance, 32(2), 261-275. https://doi.org/10.1111/j.1540-6261.1977.tb03267.x

Modigliani, F., \& Miller, M. (1963). Corporate income taxes and the cost of capital: A correction. American Economic Review, 53(3), 433-443.

Modigliani, F., \& Miller, M. H. (1958). The cost of capital, corporation finance and the theory 
of investment. American Economic Review, 48(3), 261-297.

Moosa, I., Li, L., \& Naughton, T. (2011). Robust and fragile firm-specific determinants of the capital structure of Chinese firms. Applied financial economics, 21(18), 1331-1343. https://doi.org/10.1080/09603107.2011.570714

Myers, S. C. (1977). Determinants of corporate borrowing.Journal of Financial Economics, 5(2), 147-175. https://doi.org/10.1016/0304-405X(77)90015-0

Myers, S. C. (1984). The capital structure puzzle.The Journal of Finance, 39(3), 574-592. https://doi.org/10.1111/j.1540-6261.1984.tb03646.x

Myers, S. C., \&Majluf, N. S. (1984). Corporate financing and investment decisions when firms have information that investors do not have. Journal of Financial Economics, 13(2), 187-221. https://doi.org/10.1016/0304-405X(84)90023-0

Ozkan, A. (2001). Determinants of capital structure and adjustment to long run target: evidence from UK company panel data. Journal of Business Finance \& Accounting, 28(1-2), 175-198. https://doi.org/10.1111/1468-5957.00370

Pandy, I. M. (2008). Financial Management, Vikas Pub. House Pvt. Ltd., Noida, 9th ed. Reprint, 520.

Qian, Y., Tian, Y., \&Wirjanto, T. S. (2009). Do Chinese publicly listed companies adjust their capital structure toward a target level? China Economic Review, 20(4), 662-676. https://doi.org/10.1016/j.chieco.2009.06.001

Rajan, R. G., \&Zingales, L. (1995). What do we know about capital structure? Some evidence from international data. The Journal of Finance, 50(5), 1421-1460. https://doi.org/10.1111/j.1540-6261.1995.tb05184.x

Stiglitz, J. E. (1972). Some aspects of the pure theory of corporate finance: bankruptcies and take-overs. The Bell Journal of Economics and Management Science, 458-482. https://doi.org/10.2307/3003033

Stulz, R. (1990). Managerial discretion and optimal financing policies. Journal of financial Economics, 26(1), 3-27. https://doi.org/10.1016/0304-405X(90)90011-N

Tian, L., \& Estrin, S. (2007). Debt financing, soft budget constraints, and government ownership: evidence from China. Economics of Transition, 15(3), 461-481. https://doi.org/10.1111/j.1468-0351.2007.00292.x

Titman, S., \& Grinblatt, M. (1998). Financial market and corporate strategy. US: McGrawHill.

Titman, S. (1984). The effect of capital structure on a firm's liquidation decision. Journal of financial economics, 13(1), 137-151. https://doi.org/10.1016/0304-405X(84)90035-7

Titman, S., \& Wessels, R. (1988). The determinants of capital structure choice. The Journal of Finance, 43(1), 1-19. https://doi.org/10.1111/j.1540-6261.1988.tb02585.x 


\section{Macrothink}

Asian Journal of Finance \& Accounting

ISSN 1946-052X

2018, Vol. 10, No. 2

Vijayakumaran, R. (2014). Corporate governance and corporate finance: evidence from Chinese listed companies. Unpublished doctoral dissertation. Durham University, Durham. Retrieved from http://etheses.dur.ac.uk/10965/

Vijayakumaran, R. (2015). Capital structure decisions, agency conflict and corporate performance: evidence from Sri Lankan listed manufacturing companies. International Journal of Accounting and Business Finance, 1(1), 1-14. Retrieved from https://papers.ssrn.com/sol3/papers.cfm?abstract_id=2666511

Vijayakumaran, R., (2017). Capital structure decisions and corporate performance: evidence from Chinese listed industrial firms. International Journal of Accounting and Financial Reporting, 7(2). https://doi.org/10.5296/ijafr.v7i2

Vijayakumaran, R., \&Vijayakumaran, S. (2011). Determinants of capital structure in Sri Lanka: evidence from panel data. Proceedings of the international conference, of the international conference of Sri Ram Institute of Management Studies, India, 295-305.

Vijayakumaran, R., \& Vijayakumaran, S. (2017). Institutional reforms and development of corporate governance and banking system in China. Asian Journal of Finance \& Accounting, 9(2), 352-368. https://doi.org/10.5296/ajfa.v9i2.12382

Vijayakumaran, S. (2016).Leverage and debt maturity of Chinese listed firms: determinants and effects on corporate performance, Doctoral dissertation, Durham University. Retrieved from http://etheses.dur.ac.uk/11897/

Wald, J. K. (1999). How firm characteristics affect capital structure: An international comparison. Journal of Financial Research, 22(2), 161-187. https://doi.org/10.1111/j.1475-6803.1999.tb00721.x

Wiwattanakantang, Y. (1999). An empirical study on the determinants of the capital structure of Thai firms. Pacific-Basin Finance Journal, 7(3-4), 371-403. https://doi.org/10.1016/S0927-538X(99)00007-4

Zhang, T. (2008). The problems and causes of capital structure within Chinese listed firms. Journal of Yunnan University, 3(1), 13-16.

Zou, H., \& Xiao, J. Z. (2006).The financing behaviour of listed Chinese firms. The British Accounting Review, 38(3), 239-258. https://doi.org/10.1016/j.bar.2006.04.008 